Eventos 



\title{
EnCONTROS E (DES)ENCONTROS DA ATUAÇÃo PROFISSIONAL: CONTRIBUIÇÕES DA PSICOLOGIA COMUNITÁRIA E DA ECONOMIA SOLIDÁRIA ${ }^{\star}$
}

\author{
Rodrigo Diaz de Vivar Y Soler $\star$ \\ Edelu Kawahala $\star \star \star$
}

\begin{abstract}
Palavras-chave: Psicologia Comunitária; Economia Solidária; Atuação Profissional.
\end{abstract}

Este estudo versa sobre a labuta diária de mulheres negras, pobres e semi-alfabetizadas que se embrenham num cotidiano tão duro quanto rotineiro para garantir a manutenção da sobrevivência e de si e da prole. Por outro lado, os objetivos gerais deste, consistem em observar e intervir sobre esta realidade, sob os limites de um estágio acadêmico em Psicologia Social Comunitária. Objetiva-se a partir deste, contribuir para fomentar as discussões que engendram os limites e possibilidades de atuação dos (aspirantes a) psicólogos comunitários, no que se refere ao tema trabalho e auto-gestão. O método utilizado para aproximar-se destes objetivos se inspirou em pressupostos da Investigação Ação Participante e, para tal foram privilegiadas as técnicas de observações participantes, relatos de história de vida e grupos operativos centrados na tarefa de promover ações que fortalecessem a conduta emancipatória dos participantes. Estas atividades foram registradas sistematicamente através de um diário de campo, como também partilhadas e discutidas com os participantes deste estudo. Deste processo resultou a constituição de um grupo de geração de renda através de confecções de artefatos de decoração de roupas, formado por mulheres. Do ponto de vista subjetivo, ressalta-se uma maior participação da comunidade em assuntos do dia-a-dia que envolviam a política local e a participação social, elementos necessários na construção da autonomia e da cidadania.

^ Este trabalho foi apresentado no III ENCONTRO REGIONAL DAABEP/SC: A FORMAÇÃO EM PSICOLOGIA E POLÍTICAS PÚBLICAS, realizado em Palhoça/SC, no campus da Universidade do Sul de Santa Catarina - UNISUL entre os dias: 11, 12 e 13 de Setembro de 2008.

$\star \star$ Bacharel em Psicologia pela Universidade do Extremo Sul Catarinense - UNESC. Aluno regular do Mestrado em Psicologia pela Universidade Federal de Santa Catarina - UFSC.

$\star \star \star$ Mestre em Psicologia pela UFSC. Foi orientadora do estágio quando professora da UNESC. Atualmente é aluna especial do doutorado em Psicologia pela UFSC. End.: Vereador Mario Coelho Pires, 221, bl.A, apto. 1302, Campinas, São José/SC. CEP: 88101280.

E-mail: edelukaw@hotmail.com 
